\title{
Time to abandon the bio-bio-bio model of psychosis: Exploring the epigenetic and psychological mechanisms by which adverse life events lead to psychotic symptoms
}

\author{
JOHN READ, RICHARD P. BENTALL, ROAR FOSSE
}

\begin{abstract}
Mental health services and research have been dominated for several decades by a rather simplistic, reductionistic focus on biological phenomena, with minimal consideration of the social context within which genes and brains inevitably operate. This 'medical model' ideology, enthusiastically supported by the pharmaceutical industry, has been particularly powerful in the field of psychosis, where it has led to unjustified and damaging pessimism about recovery. The failure to find robust evidence of a genetic predisposition for psychosis in general, or 'schizophrenia' in particular, can be understood in terms of recently developed knowledge about how epigenetic processes turn gene transcription on and off through mechanisms that are highly influenced by the individual's socio-environmental experiences. To understand the emerging evidence of the relationship between adverse childhood events and subsequent psychosis, it is necessary to integrate these epigenetic processes, especially those involving the stress regulating functions of the HPA axis, with research about the psychological mechanisms by which specific types of childhood trauma can lead to specific types of psychotic experiences. The implications, for research, mental health services and primary prevention, are profound.

Declaration of Interest: None of the authors have any conflicts of interest in relation to this paper.
\end{abstract}

KEY WORDS: sexual abuse in childhood, psychosis, mechanism of psychiatric symptoms.

\section{THE FAILURE OF' THE SEARCH FOR A GENETIC PREDISPOSITION}

The originators of the stress-vulnerability model of schizophrenia (Zubin \& Spring, 1977) assumed that vulnerability to stress could be acquired "due to the influence of trauma, specific diseases, perinatal complications, family experiences, adolescent peer interactions, and other life events". Most genetic and brain researchers, however, have either ignored the psychosocial causes of psychosis or relegated them to the role of triggers or exacerbators of a vulnerability which they assumed to be genetic. Meanwhile brain researchers identified abnormalities in 'schizophrenics' without considering what might have happened in their lives to have caused them. The ratio of biological to psycho-social etiology studies, 16 to one, has become increasingly imbalanced (see Table I).

Address for correspondence: Professor J. Read, Department of Psychology, Faculty of Science, University of Auckland, Room: 721.305, Tamaki Campus, Auckland (New Zealand).

E-mail: j.read@auckland.ac.nz
The hypothesis that there is a specific genetic predisposition for schizophrenia may be one of the costliest blind alleys in the history of medical research. Recent editorials suggest that 'the inconsistent results and disappointing findings of genetic research on schizophrenia' arise from 'failure to demonstrate the existence of a unitary disease process' (Ruggeri \& Tansella, 2009) and that 'the difficulty in gaining a consistent and clear-cut picture of the genetics of schizophrenia mirrors the marked clinical and neurobiological heterogeneity of the disorder' (Tosato \& Lasalvia, 2009).

The construct of 'schizophrenia' is indeed heterogeneous. It is also disjunctive and has little reliability or validity (Bentall, 2003; 2009; Read, 2004a), rendering it very difficult to identify any specific cause, genetic or otherwise. Reviewing the methodologies and concepts deployed in the search for a genetic predisposition shows that there is no robust evidence for it (Joseph, 2006). A recent paper in the American Journal of Psychiatry (Sanders et al., 2008), described by the editor as "The most comprehensive genetic association study of genes previously reported to contribute to the susceptibility to schizophrenia" (Hamilton, 2008), found that "none of the polymorphisms were associated with the schizophrenia phenotype at a reasonable threshold for statistical signif- 
Table I - Proportions of 'schizophrenia' research investigating child abuse, poverty, biological etiology and drug treatment.

\begin{tabular}{|c|c|c|c|c|c|c|}
\hline & All & $\begin{array}{l}\% \text { of all } \\
\text { schizophrenia } \\
\text { research }\end{array}$ & $\begin{array}{l}\text { Before } \\
2000\end{array}$ & $\begin{array}{c}\% \text { of all } \\
\text { schizophrenia } \\
\text { research }\end{array}$ & $\begin{array}{l}2000 \\
-M a y \\
2009\end{array}$ & $\begin{array}{l}\text { \% of all } \\
\text { schizophrenia } \\
\text { research }\end{array}$ \\
\hline $\begin{array}{l}\text { Schizophrenia } \\
\text {...and... }\end{array}$ & 75,063 & & 48,061 & & 27,002 & \\
\hline Child abuse and neglect ${ }^{1}$ & 262 & $0.3 \%$ & 142 & $0.3 \%$ & 120 & $0.4 \%$ \\
\hline Poverty $^{2}$ & 704 & $0.9 \%$ & 462 & $1.0 \%$ & 242 & $0.9 \%$ \\
\hline Biological causes $^{3}$ & 15,481 & $20.6 \%$ & 8,023 & $16.7 \%$ & 7,458 & $27.6 \%$ \\
\hline Drug Therapy ${ }^{4}$ & 14,077 & $18.8 \%$ & 7,832 & $16.3 \%$ & 6,345 & $23.1 \%$ \\
\hline Ratio of Biological causes to Social causes & $16.0: 1$ & & 13.3:1 & & $20.6: 1$ & \\
\hline
\end{tabular}

key words entered:

'child abuse' 'child neglect' 'emotional abuse' 'sexual abuse' psysical abuse'

"poverty' 'socioeconomic status'

'neurotransmitters' 'brain' 'genetics'

4'drug therapy' 'antipsychotics'

${ }^{5}$ Ration of 3 to $(1+2)$

icance' and 'of the 69 SNPs (single nucleotide polymorphisms) ... only four showed even nominal association. ... The distribution of test statistics suggests nothing outside of what would be expected by chance" (p. 421).

The failure of this expensive enterprise is understandable given what we now know about the role of epigenetic processes in the control of DNA transcription. An array of processes in the chromatin in the cell nucleus turn gene transcription on and off through mechanisms that are highly influenced by the individual's socio-environmental experiences. DNA is able to fit within the cell nucleus by being tightly wrapped around histone proteins, which have "tails" that function as the target for acetyl groups. Gene transcription is made possible when acetyl groups bind to histone tails through an enzymatic process. Without this binding DNA is closed for expression. A complementary epigenetic process occurs when a methyl group binds to the cytosine part of a cytosine-guanine base pair on the DNA, termed methylation, leading to the suppression of gene expression. We now know that the functional properties of DNA are controlled by complex interactions between histone acetylation, cytosine methylation and a range of other epigenetic processes that change the properties and structure of the chromatin in the cell nucleus (Champagne \& Curley, 2009).

In the central nervous system, these processes are specifically sensitive to an individual's psycho-social experience; hence neuropsychological development from birth to adulthood is governed by epigenetic mechanisms which are shaped by interactions with the environment (Champagne \& Curley, 2009). This is particularly pronounced in limbic structures such as the hippocampus, where the processing of psycho-social stress factors as well as the general dynamics of learning and memory are tightly coupled to modification of epigenetic state. This means that, at the cellular level, a new picture is emerging of how our biological heritage interacts with the environment, and in this picture, the environment seems to play a much more crucial role than hitherto thought. This emerging view also suggests that the idea that specific DNA polymorphisms provide a vulnerability to mental health problems may be seriously flawed (Fosse, in press).

\section{THE PSYCHO-SOCIAL CAUSES OF PSYCHOSIS}

The psycho-social factors which increase the risk of psychosis fall primarily in the domain of relational stress. Their impact is often, directly or indirectly, on the quality of relationships with other people, mediated (as discussed later) by psychological and brain adaptations to the original stressors.

Poverty, which operates in multiple ways to increase exposure to stress and to inhibit self-esteem and secure attachments, was first implicated in psychosis 70 years ago (Faris \& Dunham, 1939). By 1980 the relationship between poverty and 'schizophrenia' was described as 'one of the most consistent findings in the field of psychiatric epidemiology' (Eaton, 1980). Attempts to explain away its causal role with the 'social drift' hypothesis failed to produce convincing evidence (Read, 2004b). Contrary to the notion that 'schizophrenia' is a particularly biologically-based disorder it has repeatedly been demonstrated that poverty is even more strongly related to the diagnosis and to psychosis in general than to other disorders (Read, 2004b). For example, British children raised in economic deprivation were found to be four times more likely to develop 'non-schizophrenic' disorders but eight times more likely to grow-up to be 'schizophrenic' (Harrison et al., 2001). Among those with no 
family history of psychosis, the deprived children were seven times more likely to develop schizophrenia. The relationship between urban living and psychosis also remains after controlling for family history of psychiatric disorder (Lewis et al., 1992; Mortensen et al., 1999).

Other social factors (many related to poverty) now known to have a causal role, or to be significant risk factors, for psychosis include: mother's health, nutrition and stress during pregnancy; being the product of an unwanted pregnancy; early loss of parents via death or abandonment; separation of parents; witnessing inter-parental violence; dysfunctional parenting (often intergenerational) - particularly affectionless over-control; childhood sexual, physical and emotional abuse; childhood emotional or physical neglect; bullying; war trauma; rape or physical assaults as an adult; racist or other forms of discrimination; and heavy marijuana use early in adolescence (Bentall \& Fernyhough, 2008; Conus et al., 2009; Janssen et al., 2003; Larkin \& Morrison, 2006; Larkin \& Read, 2008; Morgan \& Fearon, 2007; Moscowitz et al., 2009; Read et al., 2004a; 2005; 2008; Schreier et al., 2009; Shevlin et al., 2009a, b; Verdoux \& Tournier, 2004; Welham et al., 2009; and see Table II). Many of these events occur in childhood, are in the domain of relational stress, and seem to increase the probability of subsequent psychosis via the creation of long-lasting insecure attachment patterns (Read \& Gumley, 2008).

It should not be surprising that psychosis, which can involve severely distressing symptoms, is caused by adverse events in childhood. Child abuse is related to disturbance severity no matter how it is measured. Patients abused as children have earlier first admissions and longer and more frequent hospitalisations, spend longer in seclusion, receive more medication, self-mutilate more, have higher global symptom severity $(9,11-15)$ and try to kill themselves more often (Read et al., 2005; 2008; Conus et al., 2009).

The idea that psychosis is socially caused is not surprising to the public. Studies in 16 countries find that when asked what causes 'schizophrenia' most people, including patients and their family members, place far more emphasis on social factors like abuse and poverty than on faulty brains or genes (Magliano et al., 2009; Read, 2007; Read et al., 2006) Furthermore, attempts to improve 'mental health literacy' (the term used by biological psychiatrists for the extent to which others agree with them), by promulgating the 'medical model', increase fear and prejudice (Angermeyer \& Matschinger, 2003; Read, 2007; Read et al., 2006).

After having been ignored for decades, the relationship between psychosis and childhood trauma has recently been studied intently (Bendall et al., 2008; Morgan \& Fisher, 2007; Read et al., 2005; Johnstone, 2009). A recent review found, from an analysis of 59 studies, that an average of $55 \%$ of male, and $65 \%$ of female, psychiatric inpatients had been either sexually or physically abused as children (Read et al., 2008). These reviews report numerous studies, using clinical diagnoses or research measures, showing that childhood emotional, physical and sexual abuse, and childhood neglect, are related to psychosis.

Ten out of eleven recent large-scale general population studies have found, even after controlling for other factors including family history of psychosis, that child maltreatment is significantly related to psychosis (Table II). For example, a prospective Netherlands study controlled for both family mental health care and history of hallucinations or delusions in first-degree relatives and found that people who had been abused as children were nine times more likely than non-abused people to experience pathology-level psychosis (Janssen et al., 2004).

Nine of the 11 studies tested for, and found, a doseresponse relationship. The most recent prospective study, of 6,437 British children, found that those who had been exposed, at age eight or ten, to either overt bullying or relational bullying (rejection by peers) were twice as likely to experience psychotic symptoms at age 12; while those who were victims of both types of bullying were 4.7 times more likely to experience psychotic symptoms (Shreier et al., 2009). The dose response relationship between severity of abuse and psychosis is also found in smaller studies targeting psychotic or abused samples (eg Kilcommons et al., 2008).

The reviews also report studies showing a relationship between abuse and the actual content of hallucinations and delusions (e.g. Read et al., 2003). They also conclude that abuse disclosures by people diagnosed 'schizophrenic' are reliable (Fisher et al., in press; Read et al., 2003; 2005; 2008).

Even within samples diagnosed psychotic or 'schizophrenic', child abuse is related to longer duration of untreated psychosis, poorer premorbid functioning, substance abuse, other diagnoses (especially depression and PTSD), unemployment, poor engagement with services, low medication compliance, low satisfaction with diagnosis and treatment, and, most importantly, suicidality (Lecomte et al., 2008; Read et al., 2005; 2008).

The relationship between adverse events in childhood and negative outcomes is confirmed by seven studies of first episode psychosis (see Conus et al., 2009). One (Fisher et al., 2009) found the abuse-psychosis relationship in women but not in men (which might be explained by gender-specific responses to trauma, and the greater

Epidemiologia e Psichiatria Sociale, 18, 4, 2009 
J. Read et al.

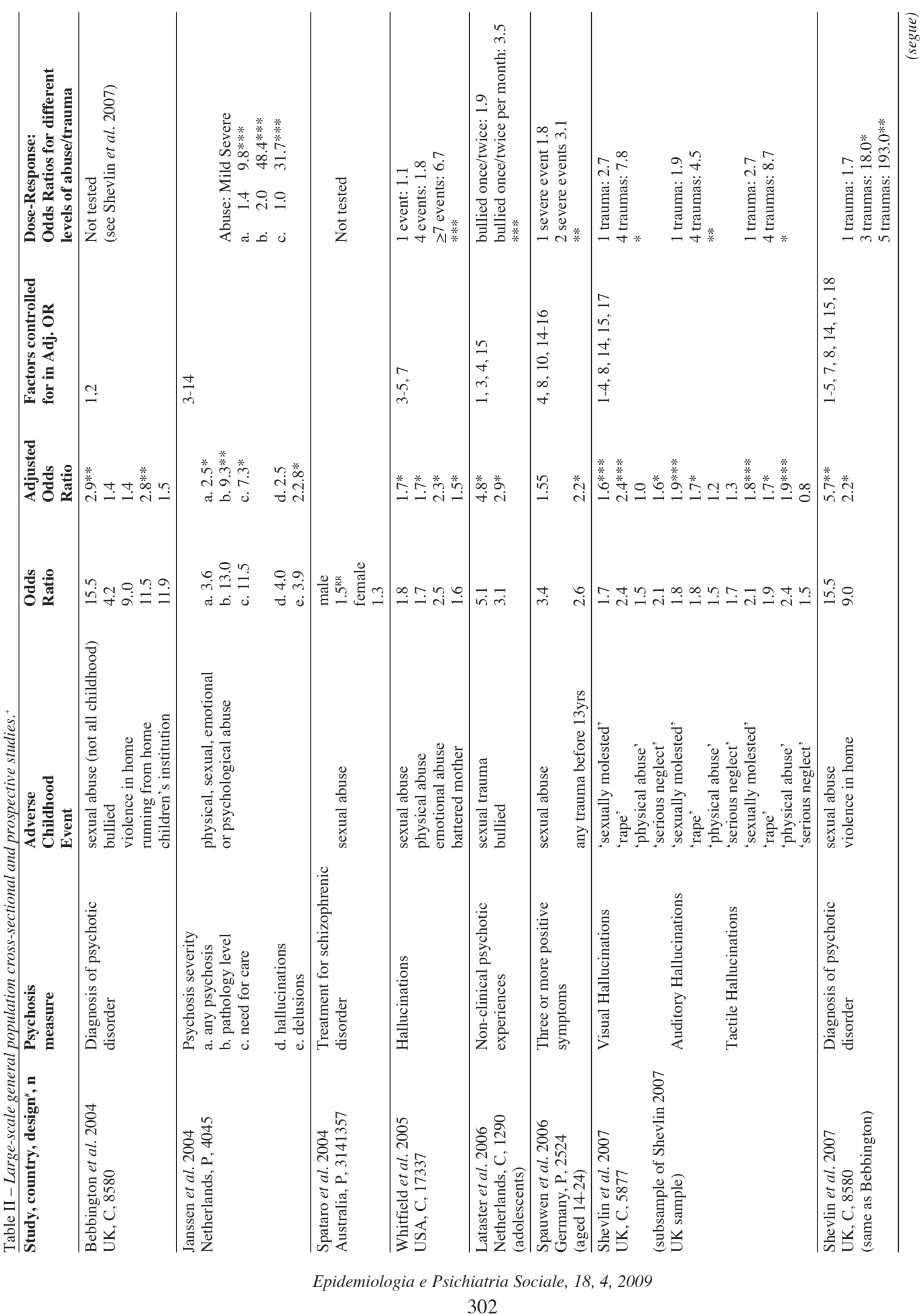


Time to abandon the bio-bio-bio model of psychosis

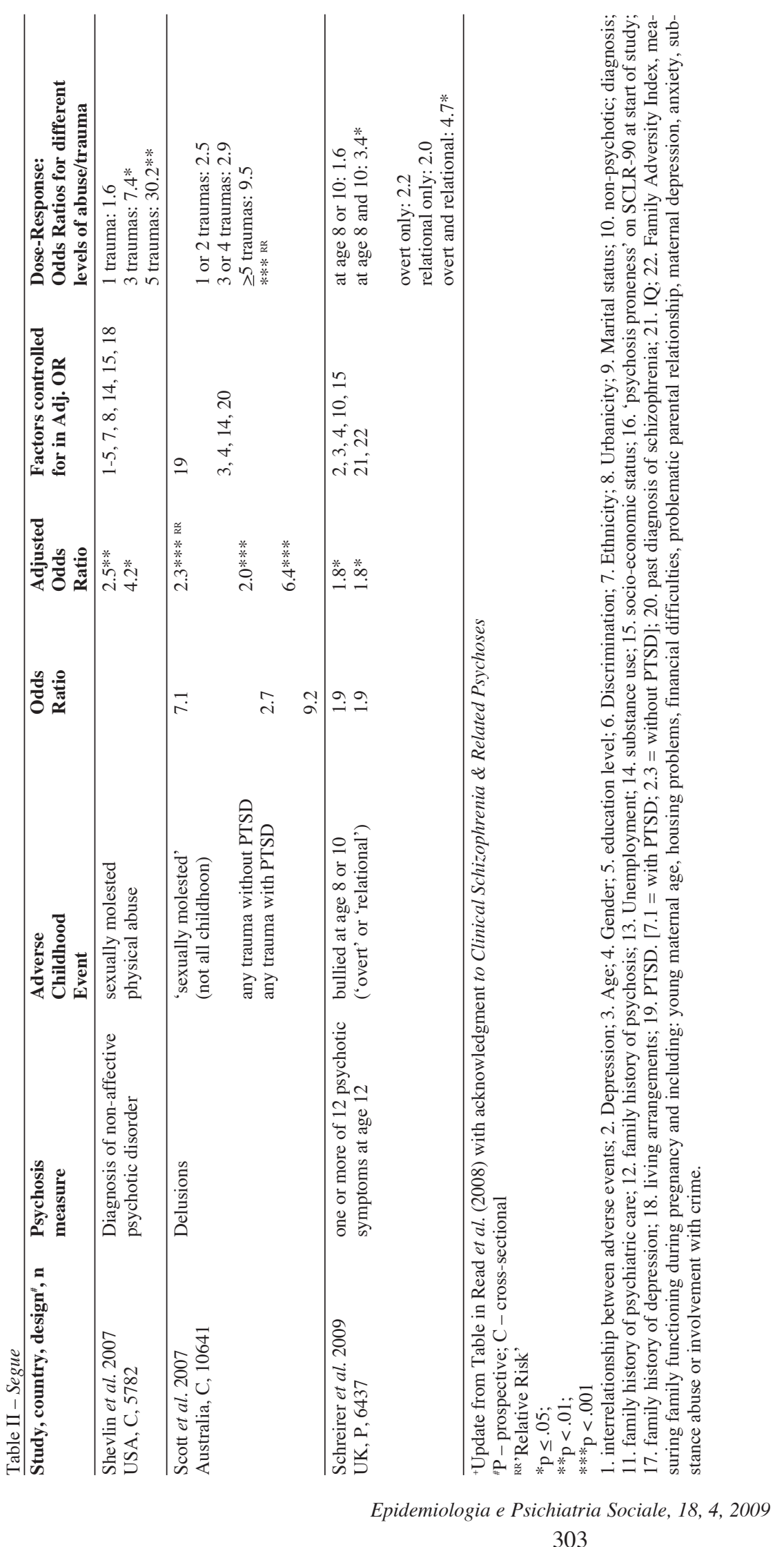

303 
likelihood of abused males entering the criminal justice system or killing themselves). The largest first-episode study to date found that child physical or sexual abuse was significantly related to numerous outcomes including substance abuse and suicide attempts, and, crucially, that the trauma preceded the psychosis in $98 \%$ of the cases (Conus et al., 2009).

\section{UNDERSTANDING THE PSYCHO-SOCIAL CAUSES: EPIGENETICS AND THE HPA AXIS}

The interactive dynamics of epigenetic processes make clear how psychosocial adversities can give rise to mental health problems. A recent example of the basic science research on this topic has been performed by Meaney and his co-workers in Canada, using rodent models of maternal care. This research shows that the frequency of licking and grooming by the dam in early life governs the development of brain and behaviour in the offspring with effects that lasts into adult life (Champagne \& Curley, 2009). Poor and absent maternal care directly affects and shapes the activity of the hypothalamus-pituitary-adrenal (HPA) axis, the main stress system of the brain, as well as its forebrain regulation systems, where crucial roles are played by the hippocampus and the medial prefrontal cortex (mPFC). Pups exposed to poor maternal care developed a modified, often increased, HPA axis reactivity and a breakdown in the normal down-regulation of this system following structural changes that are particularly well described in the hippocampus. Behaviourally, the exposed pups exhibited increased anxiety, fear and startle responses, passivity, and reduced explorative behaviour in novel situations in adult life, and females tended to exhibit the same behaviour towards their own pups as they had experienced postnatally. The molecular mechanisms involved are epigenetic processes, which become shaped by the psychosocial experience and in turn modify gene expression and thus brain development to fit the "forecast" provided by the postnatal environment. Meaney and coworkers showed that rodent maternal care affects the transcription of genes that support glucocorticoid receptors (GRs), which are central to the forebrain regulation of the HPA axis, with poor care leading to a down-regulation of these receptors through increased methylation of DNA regions in the nuclei of hippocampal neurons.

Marked changes in structure and function are documented within the HPA axis as well as its forebrain regulation regions in both first-episode and sustained psychosis.
MRI studies show an increased size of the hypothalamus, including the paraventricular nucleus that governs the HPA-axis (Goldstein et al., 2007). The normal, dynamic development of the pituitary from childhood to adult life also is changed, with increased size prior to and during psychosis debut, followed by a decreased size in more chronic states as compared to normal healthy people (Pariante et al., 2005; Pariante, 2008). In line with these changes are altered diurnal levels of cortisol elicited from the adrenal gland and increased release of cortisol following challenge (e.g. Newcomer et al., 1991).

Changes in the forebrain regulation of the HPA-axis in psychosis are evident in the decreased level of mRNA expression for glucocorticoid receptors (GRs), being documented in the hippocampi, amygdalae, and prefrontal cortices (Perlman et al., 2004; Webster et al., 2002). Volume loss in gray matter is well documented in the hippocampus and found also in the mPFC, including the control regions of emotion and motivation in the anterior cingulate (Shenton et al., 2001). The hippocampal and prefrontal changes include the density, size and shape of pyramidal cells and interneurons, and in the former region, reduced receptor expression, dendrite branching, and messenger RNA expression (Benes \& Berretta 2001; Harrison, 2004; Shenton et al., 2001). Moreover, the volume loss in the medial temporal cortex, that includes the hippocampus, correlates markedly with the reductions seen in the anterior cingulate and in the superior temporal lobe which includes the primary auditory cortex (see Shenton et al., 2001), suggesting an integrated change in forebrain regions. This plethora of findings is fully consistent with models suggesting a primary role of trauma in the development of psychosis, such as the Traumagenetic Neurodevelopmental (TN) Model (Read et al., 2001). An explicit test of the TN model found that within a sample of schizophrenia patients those abused as children (especially those emotionally abused) to have greater HPA axis dyregulation, measured by cortisol levels, than their non-abused counterparts (Brahler et al., 2005). Similarly, problems in childhood attachment can alter the structures, neuro-chemicals, and connectivity of the brain. Like CPA and CSA, severe child neglect affects the ability of the HPA axis to regulate the body and brain's stress response (Corbin. 2007).

\section{UNDERSTANDING THE PSYCHO-SOCIAL CAUSES: PSYCHOLOGICAL PROCESSES IN HALLUCINATIONS AND DELUSIONS}

In parallel to the brain's adaptations to trauma and neglect psychological processes are also, of course, 
affected. Obviously, for example, there is a psychological equivalent to the brain's over-reactivity to stress following early trauma. Psychological adaptation to adverse events, especially in childhood, tend, understandably to be in the domains of attachment and how we experience other people, including the extent to which we blame others when negative or stressful events occurs. As we shall see, however, other, perhaps less obvious, processes can also be at work. In order to understand the psychological mechanisms involved in pathways from trauma to psychosis it can be helpful to focus on specific types of trauma and specific types of psychotic experiences. For example, early childhood trauma, such as sexual abuse, seems to be particularly implicated in auditory verbal hallucinations (Hammersley et al., 2003; Read et al., 2003; Shevlin et al., 2007) but less so in paranoid delusions.

\section{HALLUCINATIONS}

Researchers have converged on a consensus account of the mechanisms involved in hallucinations, which assumes that they occur when internal, self-generated mental contents are attributed to a source that is alien or external to the self (Bentall, 1990). In the case of auditory-verbal hallucinations (AVHs), it is inner speech (the internal dialogue which forms an important role in everyday thinking) that is misattributed. The primary evidence that this is the case comes from studies that have recorded the physiological concomitants of inner speech in hallucinating patients. For example, it has been known for more than half a century that AVHs are accompanied by covert activations of the speech musculature that can be detected by electromyography (Gould, 1948; Inouye \& Shimizu, 1970; McGuigan, 1966); these kind of covert activations, known as subvocalisations, occur during normal verbal thought, and are thought to be neuromuscular echoes of the phase of childhood when children learn to speak to themselves, first out aloud and then silently (Berk, 1994). Recent PET and fMRI studies have confirmed that AVHs are accompanied by activations of the frontal brain regions involved in speech generation, and in the more posterior regions involved in speech perception (Jones \& Fernyhough, 2007).

Psychological studies using signal detection (Barkus et al., 2007; Bentall \& Slade, 1985; Rankin \& O'Carrol, 1995) and other methodologies (Bentall et al., 1991; Brebion et al., 2000; Johns et al., 2001; Morrison \& Haddock, 1997) have confirmed that ordinary people who have a high predisposition towards hallucination, and also patients who hear voices, are impaired at source monitoring (the skill of distinguishing between self-generated thoughts and perceptions) compared to appropriate controls. In a series of elctrophysiological studies, Ford \& Mathalon (2004) showed that, whereas normal inner speech is associated with signals from the frontal cortex which suppress activity in the auditory cortex, these signals are absent in patients with AVHs. Hence it seems likely that the poor source monitoring of hallucinating patients is a consequence of the failure of this mechanism which, in ordinary people, prevents self-generated speech from being mistaken from the speech of other people.

There are two possible psychological mechanisms that might link trauma to this impairment. First, poor source monitoring might be a vulnerability factor which only causes AVHs when a person experiences uncontrollable, trauma-related thoughts and memories. This hypothesis is plausible because the uncontrollable intrusive thoughts of PTSD victims are, in many ways, phenomenologically similar to AVHs and because experimental studies show that spontaneous thoughts of this kind are particularly difficult to source monitor (Johnson et al., 1993). An alternative possibility is that trauma directly interferes with the source monitoring mechanism.

\section{PARANOID DELUSIONS}

Paranoid beliefs tend to arise against a background of chronic victimization and powerlessness (Janssen et al., 2003; Mirowsky \& Ross, 1983). There is also evidence that both patients (Dozier \& Lee, 1995) and ordinary people with sub-clinical paranoia (Pickering et al., 2008) tend to have severe attachment difficulties. These observations may help to explain why early separation from parents (Morgan et al., 2007) and being unwanted at birth (Myhrman et al., 1996) increase the risk of later psychosis, and also why immigrant groups (who are vulnerable to victimization) are especially likely to develop psychosis, typically with paranoia (Harrison et al., 1988; Selten et al., 2001).

The core of paranoia is the excessive estimation of personal threat (Bentall et al., 2009). As the striatal dopamine system plays a role in anticipating aversive events, it seems likely that, at the neurochemical level, dopaminergic abnormalities (long implicated in psychosis; Laruelle \& Abi-Dargham, 1999) underlie this excessive threat anticipation (Moutoussis et al., 2007). This abnormality, in turn, seems to be associated with problems of emotion and reasoning which are quite distinct from the source monitoring difficulties of hallucinating patients. 
Three separate mechanisms have been proposed in the psychological literature, with some evidence to support each. First, it has been suggested that delusions in general are associated with a tendency to jump to conclusions, that is, a tendency to make decisions on the basis of very little information. Although the precise nature of this deficit are currently a matter of controversy, the balance of evidence suggests that it is more evident in deluded patients than in patients with other kinds of symptoms (Dudley \& Over, 2003; Garety et al., 1991; 2005; Moritz \& Woodward, 2005). Second, it has been argued that paranoid patients may have a difficulty in 'Theory of Mind'; the ability to understand others' mental states. Frith (1994) argued that a sudden loss of ToM skills would be likely to lead to persecutory beliefs if the patient assumes that others are concealing their true intentions. Consistent with this idea, empirical studies have clearly demonstrated that ToM skills are impaired during acute episodes of psychosis, but the evidence for a specific association with paranoia is equivocal (Brune, 2005; Corcoran et al., 1997; 2008; Drury et al., 1998).

Perhaps more importantly in the present context, it has been argued that paranoia arises as a consequence of severe problems of self-esteem and an external locus of control, especially if the individual attempts to defend against feelings of low self-worth by attributing the causes of misfortunes to malevolent others (Bentall et al., 1994; 2001). Arguably, these kinds of cognitive biases are especially likely to develop against a background of attachment insecurity and victimization. Consistent with this account, paranoid patients show highly unstable selfesteem (Thewissen et al., 2007; 2008) and also marked discrepancies between implicit and explicit self-esteem (McKay et al., 2007; Moritz et al., 2006). However, an externalizing attributional bias (the specific tendency to attribute negative events to the actions of others) only seems to be present during acute episodes of paranoia (Janssen et al., 2006) when the individual is also grandiose (Jolley et al., 2006) and believes that persecution is completely undeserved (Janssen et al., 2006).

It is not known how these mechanisms, implicated in specific symptoms and related to specific types of adverse experience, relate to the epigenetic processes described earlier. However, the role of disrupted attachment in paranoia provides one point of contact between the two research literatures. Moreover, external locus of control and low self-esteem has been associated with HPA dysregulation and reduced hippocampal volume in young adults (Pruessner et al., 2005) In the case of hallucinations, matters are likely to be more complex because acute stress increases source monitoring accuracy in healthy individuals (Smeets et al., 2008) whereas, in people with hallucinations, the opposite effect seems to occur.

\section{IMPLICATIONS}

\section{Research}

A lot of money have has been wasted on well-intentioned but ultimately useless genetic research, with similar amounts poured into context-less brain research. The genuinely integrated socio-bio-psychological approach proposed in this paper, and increasingly being adopted internationally, will lead to genuinely productive research programmes, at both the theoretical and clinical levels. One review identified 37 research areas opened up by giving appropriate emphasis to all three domains in the bio-psycho-social paradigm and to the complex interactions within and between those domains (Read et al., 2004b). There is an urgent need to develop research designs which will allow the measurement of childhood adversity, the epigenetic mechanisms discussed above, or index measures (e.g. HPA functioning), together with the psychological mechanisms that are implicated in particular symptoms of psychosis.

\section{Assessment}

Many researchers advocate the screening of all mental health service users, including those diagnosed 'schizophrenic', so as to make comprehensive formulations and effective treatment plans (e.g. Conus et al., 2009). Progress towards this goal has been slow to date, but is beginning to gather pace ( $R$ ead et al., 2006). Training is essential (Read et al., 2007).

\section{Treatment}

Another consequence of the over emphasis on de-contextualised biological factors has been the unsubstantiated assumptions that virtually everyone who experiences psychosis benefits from anti-psychotic medication and that psychological interventions are somehow adjunctive to drugs. These drugs, which benefit only between a third to two-thirds of recipients (in terms of relapse prevention or symptom reduction), have serious health risks (Ross \& Read, 2004; Mosher et al., 2004), including increased mortality risk (Weinmann et al., 2009), for all recipients, leading to high levels of 'non-compliance'. A recent review of 
five studies of early psychosis found that those treated without medication fared better than those on medication (Bola et al., 2009). Meanwhile a range of psychological interventions that address the psycho-social causes and the maladaptive mechanisms identified above, have been found to be effective, at least for some patients, and are free from health risks for all (Gleeson et al., 2008; Read et al., 2004c; Alanen, 2009; Morrison, 2009). These include, but are no means limited to, cognitive therapy based on the understanding of the psychological mechanisms described earlier (Kindon \& Turkington, 2005; Morrison, 2004; 2009). Starting from the client's understanding of their experiences (Geekie \& Read, 2009), of the causes, of their problems (Magliano et al., 2009) and of how best to measure recovery (Neil et al., 2009), is paramount.

\section{Prevention}

Another consequence of a simplistic bio-genetic approach is the failure of the mental health community to lobby for primary prevention programmes aimed at keeping children securely attached and safe in the first five years of life. (Davies \& Burdett, 2004). For example, an environmental enrichment programme at age 3-5 years has been shown to reduce schizotypal traits in early adulthood (Raine et al., 2003).

\section{CONCLUSION}

We must work, across disciplinary boundaries, to build on these beginnings of a truly integrated bio-psycho-social model. This will avoid wasting more resources on unproductive research that could be better spent on focusing on what has gone on in the lives of people diagnosed 'schizophrenic' and what will best assist them with the distress and confusion that often results. This more genuinely evidence-based approach will, however, require us to question how we adopted such a narrow view in the first place, and to free our professional organizations, research journals and teaching institutions from the pervasive influence of the pharmaceutical industry (Mosher et al., 2004; Read, 2008; Shooter, 2005). The President of the American Psychiatric Association recently warned: "If we are seen as mere pill pushers and employees of the pharmaceutical industry, our credibility as a profession is compromised. As we address these Big Pharma issues, we must examine the fact that as a profession, we have allowed the bio-psycho-social model to become the bio-bio-bio model" (Sharfstein, 2005, p. 3).

\section{REFERENCES}

Alanen, Y. (2009). Towards a more humanistic psychiatry: Development of need-adapted treatment of schizophrenia group psychoses. Psychosis: Psychological, Social and Integrative Approaches 1, 156-166.

Angermeyer M. \& Matschinger H. (2003). Public beliefs about schizophrenia and depression: similarities and differences. Social Psychiatry and Psychiatric Epidemiology 38, 526-534.

Barkus E., Stirling J., Hopkins R., McKie S. \& Lewis S. (2007). Cognitive and neural processes in non-clinical auditory hallucinations. British Journal of Psychiatry 191, Suppl. 51, 76-81.

Bebbington P., Bhugra D., Brugha T., Singleton N., Farrell M., Jenkins R., Lewis G. \& Meltzer H. (2004). Psychosis, victimization and childhood disadvantage: Evidence from the second British national survey on psychiatric morbidity. British Journal of Psychiatry 185, 220-226.

Bendall S., Jackson H., Hulbert C. \& McGorry P. (2008). Childhood trauma and psychotic disorders: a systematic, critical review of the evidence. Schizophrenia Bulletin 34, 569-579.

Benes F. \& Berretta S. (2001). GABAergic interneurons: Implications for understanding schizophrenia and bipolar disorder. Neuropsychopharmacology 25, 1-27.

Bentall R. (1990). The illusion of reality: a review and integration of psychological research on hallucinations. Psychological Bulletin $107,82-95$.

Bentall R. (2003). Madness Explained: Psychosis and Human Nature. Penguin: London.

Bentall R. (2009). Doctoring the Mind: Why Psychiatric Treatments are Often Ineffective. Penguin: London.

Bentall R. \& Fernyhough C. (2008). Social predictors of psychotic experiences: Specificity and psychological mechanisms. Schizophrenia Bulletin 34, 1012-1020

Bentall R. \& Slade P. (1985). Reality testing and auditory hallucinations: a signal-detection analysis. British Journal of Clinical Psychology 24, 159-169.

Bentall R., Baker G. A. \& Havers S. (1991). Reality monitoring and psychotic hallucinations. British Journal of Clinical Psychology 30, 213-222.

Bentall R., Kinderman P. \& Kaney S. (1994). The self, attributional processes and abnormal beliefs: towards a model of persecutory delusions. Behaviour Research and Therapy 32, 331-341.

Bentall R., Corcoran R., Howard R., Blackwood N. \& Kinderman P. (2001). Persecutory delusions: a review and theoretical integration. Clinical Psychology Review 21, 1143-1192.

Bentall R., Rowse G., Shryane N., Kinderman P., Howard R., Blackwood N., Moore R. \& Corcoran R. (2009). The cognitive and affective structure of paranoid delusions: a transdiagnostic investigation of patients with schizophrenia spectrum disorders and depression. Archives of General Psychiatry 66, 236-247.

Berk L. (1994). Why children talk to themselves. Scientific American 61-65.

Bola J., Lehtinen K., Cullberg J. \& Ciompi L. (2009). Psychosocial treatment, antipsychotic postponement, and low-dose medication strategies in first-episode psychosis: a review of the literature. Psychosis: Psychological, Social and Integrative Approaches 1, 4-18.

Braehler C., Holowka D., Brunet A., Beaulieu S., Baptista T., Bebruille J-M., Walker C. \& King S. (2005). Diurnal cortisol in schizophrenia patients with childhood trauma. Schizophrenia Research 79, 353354.

Brebion G., Amador X., David A., Malaspina D. \& Sharif Z. (2000). Positive symptomatology and source monitoring failure in schizophrenia: an analysis of symptom-specific effects. Psychiatry Research 95, 119-131.

Brune M. (2005). Theory of mind' in schizophrenia: a review of the literature. Schizophrenia Bulletin 31, 21-42.

Champagne F. \& Curley J. (2009). Epigenetic mechanisms mediating the long-term effects of maternal care on development. Neuroscience and Biobehavioral Reviews 33, 593-600. 
Conus P., Cotton S., Schimmelmann B., McGorry P. \& Lambert M. (2009). Pretreatment and outcome correlates of sexual and physical trauma in an epidemiological cohort of first-episode psychosis patients. Schizophrenia Bulletin, april 21 [Epub ahead of print].

Corbin J., (2007). Reactive attachment disorder: a biopsychosocial disturbance of attachment. Child and Adolescent Social Work Journal $24,539-552$.

Corcoran R., Cahill C. \& Frith C. (1997). The appreciation of visual jokes in people with schizophrenia: a study of 'mentalizing' ability. Schizophrenia Research 24, 319-327.

Corcoran R., Rowse G., Moore R., Blackwood N., Kinderman P., Howard R., Cummins S. \& Bentall R. (2008). A transdiagnostic investigation of theory of mind and jumping to conclusions in paranoia: a comparison of schizophrenia and depression with and without delusions. Psychological Medicine 38, 1577-1583.

Davies E. \& Burdett J. (2004). Preventing 'schizophrenia': creating the conditions for saner societies. In Models of Madness (ed. J. Read, L. Mosher, R. Bentall). Routledge: London.

Dozier M. \& Lee S. (1995). Discrepancies between self and other-report of psychiatric symptomatology: Effects of dismissing attachment strategies. Development and Psychopathology 7, 217-226.

Drury V., Robinson E. \& Birchwood M. (1998). Theory of mind' skills during an acute episode of psychosis and following recovery. Psychological Medicine 28, 1101-1112.

Dudley R. \& Over D. (2003). People with delusions jump to conclusions: a theoretical account of research findings on the reasoning of people with delusions. Clinical Psychology and Psychotherapy 10, 263-274.

Eaton W. (1980). A formal theory of selection for schizophrenia. American Journal of Sociology 86, 149-158.

Faris R. \& Dunham H. (1939). Mental Disorders in Urban Areas. University of Chicago: Chicago.

Fisher H., Morgan C., Dazzan P., Craig T., Morgan K., Hutchinson G, Jones P., Doody G., Pariante C., McGuffin P., Murray R., Leff J. \& Fearon P. (2009). Gender differences in the association between childhood abuse and psychosis. British Journal of Psychiatry 194, 319-325.

Fisher H., Craig T., Fearon P., Dazzan P., Lappin J., Hutchinson G., Doody G., Jones P., McGuffin P., Murray R., Leff J. \& Morgan C. (in press). Reliability and validity of psychosis patients' retrospective reports of childhood abuse. Schizophrenia Bulletin.

Ford J. \& Mathalon D. (2004). Electrophysiological evidence of corollary discharge dysfunction in schizophrenia during talking and thinking. Journal of Psychiatric Research 38, 37-46.

Fosse R. (in press). Mot en ny forståelse av psykiske lidelser. Journal of the Norwegian Psychology Associaton.

Frith C. (1994). Theory of mind in schizophrenia. In The Neuropsychology of Schizophrenia (ed. A. David and J. Cutting). Hove: Erlbaum.

Garety P., Hemsley D. \& Wessely S. (1991). Reasoning in deluded schizophrenic and paranoid patients. Journal of Nervous and Mental Disease 179, 194-201.

Garety P., Freeman D., Jolley S., Dunn G., Bebbington P., Fowler D. Kuipers E. \& Dudley R. (2005). Reasoning, emotions and delusional convictions in psychosis. Journal of Abnormal Psychology 114, 373-384.

Geekie J. \& Read J. (2009). Making Sense of Psychosis: Contesting the Meaning of Schizophrenia. Routledge: London.

Gleeson J., Killackey E. \& Krstev H. (Eds.) (2008). Psychotherapies for the Psychoses: Theoretical, Cultural and Clinical Integration. Routledge: London.

Gould L. (1948). Verbal hallucinations and activity of vocal musculature. American Journal of Psychiatry 105, 367-372.

Goldstein J., Seidma L., Makris N., Ahern T., O'Brien L., Caviness V., Kennedy D., Faraone S. \& Tsuang M. (2007). Hypothalamic abnormalities in schizophrenia: sex effects and genetic vulnerability. Biological Psychiatry 61, 935-945

Hamilton S.P. (2008). Schizophrenia candidate genes: Are we really coming up blank? American Journal of Psychiatry 165, 420-423.
Hammersley P., Dias A., Todd G., Bowen-Jones K., Reilly B. \& Bentall R. (2003). Childhood trauma and hallucinations in bipolar affective disorder: a preliminary investigation. British Journal of Psychiatry 182, 543-547.

Harrison G., Owens D., Holton A., Neilson D. \& Boot D. (1988). A prospective study of severe mental disorder in Afro-Caribbean patients. Psychological Medicine 18, 643-657.

Harrison G., Gunnell D., Glazebrook C., Page K. \& Kwiecinski R. (2001). Association between schizophrenia and social inequality at birth. British Journal of Psychiatry 179, 346-350.

Harrison P. (2004). The hippocampus in schizophrenia: a review of the neuropathological evidence and its pathophysiological implications. Psychopharmacology (Berl) 174, 151-162.

Inouye T. \& Shimizu A. (1970). The electromyographic study of verbal hallucination. Journal of Nervous and Mental Disease 151, 415-422.

Janssen I., Hanssen M., Bak M., Bijl R., De Graaf R., Vollebergh W. \& van Os. (2003). Discrimination and delusional ideation. British Journal of Psychiatry 182, 71-76.

Janssen I., Krabbendam L., Bak M., Hanssen M., Vollebergh W., de Graaf R. \& van Os J. (2004). Childhood abuse as a risk factor for psychotic experiences. Acta Psychiatrica Scandinavica 109, 38-45.

Janssen I., Versmissen D., Campo J., Myin-Germeys I., van Os J. \& Krabbendam L. (2006). Attributional style and psychosis: evidence for externalizing bias in patients but not individuals at high risk. Psychological Medicine 27, 1-8.

Johns L., Rossell S., Frith C., Ahmad F., Hemsley D., Kuipers E. \& McGuire P. (2001). Verbal self-monitoring and auditory hallucinations in people with schizophrenia. Psychological Medicine 31, 705-715.

Johnson M., Hashtroudi S. \& Lindsay D. (1993). Source monitoring. Psychological Bulletin 114, 3-28.

Johnstone L. (2009). Controversial issues in trauma and psychosis. Psychosis: Psychological, Social and Integrative Approaches 1, 185-190.

Jolley S., Garety P., Bebbington P., Dunn G., Freeman D., Kuipers E., Fowler D. \& Hemsley D. (2006). Attributional style in psychosis: the role of affect and belief type. Behaviour Research and Therapy 44, 1597-1607.

Jones S. \& Fernyhough C. (2007). Neural correlates of inner speech and auditory verbal hallucinations: a critical review and theoretical integration. Clinical Psychology Review 27, 140-154.

Joseph J. (2006). The Missing Gene: Psychiatry, Heredity, and the Fruitless Search for Genes. Algora: New York.

Kilcommons A., Morrison, A., Knight A. \& Lobban F. (2008). Psychotic experiences in people who have been sexually assaulted. Social Psychiatry and Psychiatric Epidemiology 43, 902-611.

Kingdon D. \& Turkington D. (2005). Cognitive Therapy of Schizophrenia. Guilford Press: New York.

Larkin W. \& Morrison A. (Eds.) (2006). Trauma and Psychosis: New Directions for Theory and Therapy. Routledge: London.

Larkin W. \& Read J. (2008). Childhood trauma and psychosis: Evidence, pathways, and implications. Journal of Postgraduate Medicine 54, 284-290.

Laruelle M., \& Abi-Dargham A. (1999). Dopamine as the wind in the psychotic fire: new evidence from brain imaging studies. Journal of Psychopharmacology 13, 358-371.

Lataster T., van Os J., Drukker M., Henquet C., Feron E., Gunther N. \& Myin-Germeys I. (2004). Childhood victimization and developmental expression of non-clinical delusional ideation and hallucinatory experiences. Social Psychiatry and Psychiatric Epidemiology 41, 423-428.

Lecomte T., Spidel A., Leclerc C., MacEwan W., Greaves C. \& Bentall R. (2008). Predictors and profiles of treatment non-adherence and engagement in service problems in early psychosis. Schizophrenia Research 102, 295-302.

Lewis G., David A. \& Andreasson S. (1992). Schizophrenia and city life. Lancet 340, 137-140.

Magliano L., Fiorillo A., Del Vecchio H., Malangone C., De Rosa C., Bachelet C., Truglia E., D’Ambrogio R.,. Pizzale F, Veltro F., Zanus P., Pioli R. \& Maj M. (2009). What people with schizophrenia think about the causes of their disorder. Epidemiologia e Psichiatria Sociale $18,48-53$ 
McGuigan F. (1966). Covert oral behavior and auditory hallucinations. Psychophysiology 3, 73-80.

McKay R., Langdon R., \& Coltheart M. (2007). The defensive function of persecutory delusions: an investigation using the implicit association test. Cognitive Neuropsychiatry 12, 1-24.

Mirowsky J. \& Ross C. (1983). Paranoia and the structure of powerlessness. American Sociological Review 48, 228-239.

Morgan C. \& Fearon P. (2007). Social experience and psychosis. Insights from studies of migrant and ethnic minority groups. Epidemiologia e Psichiatria Sociale 16, 118-123.

Morgan C. \& Fisher H. (2007). Environment and schizophrenia: environmental factors in schizophrenia: childhood trauma - a critical review. Schizophrenia Bulletin 33, 3-10.

Morgan C., Kirkbride J., Leff J., Craig T., Hutchinson G., McKenzie K., Morgan,K., Dazzan P., Doody G., Jones P., Murray R. \& Fearon P. (2007). Parental separation, loss and psychosis in different ethnic groups: a case-control study. Psychological Medicine 37, 495-503.

Moritz S. \& Woodward T.S. (2005). Jumping to conclusions in delusional and non-delusional schizophrenic patients. British Journal of Clinical Psychology 44, 193-207.

Moritz S., Werner R. \& von Collani G. (2006). The inferiority complex in paranoia readdressed: a study with the Implicit Association Test. Cognitive Neuropsychiatry 11, 402-415.

Morrison A. (2004). Cognitive Therapy for Psychosis: A Formulationbased Approach. Brunner-Routledge: Hove UK.

Morrison A. (2009). Cognitive behaviour therapy for first-episode psychosis: Good for nothing or fit for purpose? Psychosis: Psychological, Social and Integrative Approaches 1, 103-112.

Morrison A. \& Haddock G. (1997). Cognitive factors in source monitoring and auditory hallucinations. Psychological Medicine 27, 669679.

Mortensen P., Pedersen C., Westergaard T., Wohlfahrt J., Ewald H., Mors O., Andersen P. \& Melbye M. (1999). Effects of family history and place and season of birth on the risk of schizophrenia. New England Journal of Medicine 340, 603-608.

Mosher L., Gosden R. \& Beder S. (2004). Drug companies and schizophrenia: Unbridled capitalism meets madness. In Models of Madness (ed. J. Read, L. Mosher, R. Bentall). Routledge: London.

Moskowitz A., Schafer I. \& Dorahy M. (2009). Psychosis, Trauma and Dissociation: Emerging Perspectives on Severe Psychopathology. Wiley-Blackwell: Chichester, UK.

Moutoussis M., Williams J., Dayan P. \& Bentall R. (2007). Persecutory delusions and the conditioned avoidance paradigm: towards an integration of the psychology and biology of paranoia. Cognitive Neuropsychiatry 12, 495-510.

Myhrman A., Rantakallio P., Isohanni M. \& Jones P. (1996). Unwantedness of pregnancy and schizophrenia in the child. British Journal of Psychiatry 169, 637-640.

Neil S., Kilbride M., Pitt L., Nothard S., Welford M., Sellwood W. \& Morrison A. (2009). The questionnaire about the process of recovery (QPR): A measurement tool developed in collaboration with service users. Psychosis: Psychological, Social and Integrative Approaches 1, 145-155.

Newcomer J., Faustman W., Whiteford H., Moses Jr J. \& Csernansky J. (1991). Symptomatology and cognitive impairment associate independently with post-dexamethasone cortisol concentrations in unmedicated schizophrenic patients. Biological Psychiatry 29, 855864.

Pariante C.M. (2008). Pituitary volume in psychosis: the first review of the evidence. Journal of Psychopharmacology 22, 76-81

Pariante C.M., Carmine M., Dazzan P., Danese A., Morgan K.D., Brudaglio F., Morgan C., Fearon P., Orr K., Hutchinson G., Pantelis C., Velakoulis D., Jones P.B., Left J. \& Murray R.M. (2005). Increased pituitary volume in antipsychotic-free and antipsychotictreated patients of the AEsop first-onset psychosis study. Neuropsychopharmacology 30, 1923-1931.

Perlman W., Webster M., Kleinman J. \& Weickert C. (2004). Reduced glucocorticoid and estrogen receptor-messenger ribonucleic acid levels in the amygdala of patients with major mental illness. Biological Psychiatry 56, 844-852

Pickering L., Simpson J. \& Bentall R. (2008). Insecure attachment predicts proneness to paranoia but not hallucinations. Personality and Individual Differences 44, 1212-1224.

Pruessner J., Baldwin M., Dedovic K., Renwick R., Mahani N., Lord C., Meaney M. \& Lupien S. (2005). Self-esteem, locus of control, hippocampal volume, and cortisol regulation in young and old adulthood. Neuroimage 28, 815-826.

Raine A., Mellingen K., Liu J., Venables P. \& Mednick S. (2003), Effects of environmental enrichment at ages 3-5 years on schizotypal personality and antisocial behavior at ages 17 and 23 years. American Journal of Psychiatry 160, 1627-1635.

Rankin P. \& O'Carrol P. (1995). Reality monitoring and signal detection in individuals prone to hallucinations. British Journal of Clinical Psychology 34, 517-528.

Read J. (2004a). Does schizophrenic exist? Reliability and validty. In Models of Madness: Psychological, Social and Biological Approaches to Schizophrenia (ed. J. Read, L. Mosher, R. Bentall). Routledge: London.

Read J. (2004b). Poverty, ethnicity and gender. In Models of Madness: Psychological, Social and Biological Approaches to Schizophrenia (ed. J. Read, L. Mosher, R. Bentall). Routledge: London.

Read J. (2007). Why promoting biological ideology increases prejudice against people labelled 'schizophrenic'. Australian Psychologist 42, 118-128.

Read J. (2008). Schizophrenia, drug companies and the internet. Social Science \& Medicine 66, 99-109.

Read J. \& Gumley A. (2008). Can attachment theory help explain the relationship between childhood adversity and psychosis? Attachment 2, 1-35.

Read J., Perry B., Moskowitz A. \& Connolly J. (2001). The contribution of early traumatic events to schizophrenia in some patients: a Traumagenic Neurodevelopmental model. Psychiatry: Interpersonal and Biological Processes 64, 319-345.

Read J., Agar K., Argyle N. \& Aderhold V. (2003). Sexual and physical abuse during childhood and adulthood as predictors of hallucinations, delusions and thought disorder. Psychology and Psychotherapy: Theory, Research and Practice 76, 1-22.

Read J., Goodman L., Morrison A., Ross C. \& Aderhold V. (2004a). Childhood trauma, loss and stress. In Models of Madness (ed. J. Read, L. Mosher, R. Bentall). Routledge: London.

Read J., Seymour F. \& Mosher L. (2004b). Unhappy families. In Models of Madness (ed. J. Read, L. Mosher, R. Bentall). Routledge: London.

Read J., Mosher L. \& Bentall R. (Eds). (2004c). Models of Madness: Psychological, Social and Biological Approaches to Schizophrenia. Routledge: London.

Read J., Haslam N., Sayce L. \& Davies E. (2006). Prejudice and schizophrenia: a review of the 'mental illness is an illness like any other' approach. Acta Psychiatrica Scandinavica 114, 303-318.

Read J., van Os J., Morrison A. \& Ross C. (2005). Childhood trauma, psychosis and schizophrenia: a literature review with theoretical and clinical implications. Acta Psychiatrica Scandinavica 112, 330-350.

Read J., Mcgregor K., Coggan C. \& Thomas D. (2006). Mental health services and sexual abuse: The need for staff training. Journal of Trauma and Dissociation 7, 33-50.

Read J., Hammersley P. \& Rudegeair T. (2007). Why, when and how to ask about child abuse. Advances in Psychiatric Treatment 13, 101-110.

Read J., Fink P., Rudegeair T., Felitti V. \& Whitfield C. (2008). Child maltreatment and psychosis: A return to a genuinely integrated biopsycho-social model. Clinical Schizophrenia and Related Psychoses 7, 235-254.

Ross C. \& Read J. (2004). Antipsychotic medication: myths and facts. In Models of Madness: Psychological, Social and Biological Approaches to Schizophrenia (ed. J. Read, L. Mosher, R. Bentall). Routledge: London. 
Ruggeri M. \& Tansella M. (2009). The interaction between genetics and epidemiology: the puzzle and its pieces. Epidemiologia $e$ Psichiatria Sociale 18, 77-80.

Sanders A., Duan J., Levinson D., Shi J., He D., Hou C., Burrell G., Rice J., Nertney D., Olincy A., Rozic P., Vinogradov S., Buccola N., Mowry B., Freedman R., Amin F., Black D., Silverman J., Byerley W., Crowe R., Cloninger C., Martinez M. \& Gejman P. (2008). No significant association of 14 candidate genes with schizophrenia in a large European ancestry sample: implications for psychiatric genetics. American Journal of Psychiatry 165, 497-506.

Schreier A., Wolke D., Thomas K., Horwood J., Hollis C., Gunnell D., Lewis G., Thompson A., Zammit S., Duffy L., Salvi G. \& Harrison G. (2009). Prospective study of peer victimization in childhood and psychotic symptoms in a nonclinical population at age 12 years. Archives of General Psychiatry 66, 527-536.

Scott J., Chant D., Andrews G., Martin G. \& McGrath J. (2007). Association between trauma exposure and delusion experiences in a large community-based sample. British Journal of Psychiatry 190, 339-343.

Selten J-P., Veen N., Feller W., Blom J., Schols D., Camoenie W., Oolders J., van der Velden M., Hoek H., Rivero V., van der Graaf Y. \& Kahn R. (2001). Incidence of psychotic disorders in immigrant groups to The Netherlands. British Journal of Psychiatry 178, 367-372.

Sharfstein S. (2005). Big Pharma and American psychiatry: the good, the bad and the ugly. Psychiatric News 40, 3.

Shenton M., Dickey C., Frumin M. \& McCarley R. (2001). A review of MRI findings in schizophrenia. Schizophrenia Research 49, 1-52.

Shevlin M., Dorahy M. \& Adamson G. (2007). Childhood traumas and hallucinations: an analysis of the National Comorbidity Survey. Journal of Psychiatric Research 41, 222-228.

Shevlin M., Murphy J., Houston J. \& Adamson G. (2009a). Childhood sexual abuse, early cannabis use, and psychosis: Testing the effects of different temporal orderings based on the National Comorbidity Survey. Psychosis: Psychological, Social and Integrative Approaches 1, 19-28.

Shevlin M., Murphy J., Houston J. \& Adams G. (2009b). Childhood sexual abuse, early cannabis use and psychosis: Testing the effects of different temporal orderings based on the National Comorbidity Survey. Psychosis: Psychological, Social and Integrative Approaches 1, 19-28.
Shooter M. (2005). Dancing with the devil? A personal view of psychiatry's relationship with the pharmaceutical industry. Psychiatric Bulletin 29, 81-83.

Smeets T., Sjistermans K., Gijsen C., Peters M., Jelicic M. \& Merckelbach, H. (2008). Acute consolidation stress enhances reality monitoring in healthy young adults. Stress 11, 235-245.

Spataro J., Mullen P., Burgess P., Wekks D. \& Moss S. (2004). Impact of child sexual abuse on mental heatlh: prospective study in males and females. British Journal of Psychiatry 184, 416-421.

Spauwen J., Krannebdam L., Lieb R., Wittchen H. \& van Os J. (2006). Impact of psychological trauma on the development of psychotic symptoms: Relationship with psychosis proneness. British Journal of Psychiatry 188, 527-533.

Thewissen V., Myin-Germeys I., Bentall R., de Graaf R., Vollenberg W. \& van Os J. (2007). Instability in self-esteem and paranoia in a general population sample. Social Psychiatry and Psychiatric Epidemiology 42, 1-5.

Thewissen V., Bentall R., Lecomte T., van Os J. \& Myin-Germeys I. (2008). Fluctuations in self-esteem and paranoia in the context of everyday life. Journal of Abnormal Psychology 117, 143-153.

Tosato S. \& Lasalvia A. (2009). The contribution of epidemiology to defining the most appropriate approach to genetic research on schizophrenia. Epidemiologia e Psichiatria Sociale 18, 81-90.

Verdoux H. \& Tournier M. (2004). Cannabis use and risk of psychosis: An etiological link? Epidemiologia e Psichiatria Sociale 13, 113119.

Webster M., Knable M., O'Grady J., Orthmann J. \& Weickert C. (2002). Regional specificity of brain glucocorticoid receptor mRNA alterations in subjects with schizophrenia and mood disorders. Molecular Psychiatry 7, 985-94

Weinman S., Read J. \& Aderhold V. (2009). The influence of antipsychotics on mortality in schizophrenia: A systematic review. Schizophrenia Research 113, 1-11.

Welham J., Isohanni M., Jones P. \& McGrath J. (2009). The antecedents of schizophrenia: a review of birth cohort studies. Schizophrenia Bulletin 35, 603-623.

Whitfield C., Dube S., Felitti V. \& Andra R. (2005). Adverse childhood experiences and hallucinations. Child Abuse \& Neglect 29, 797-810.

Zubin J. \& Spring B. (1977). Vulnerability - a new view of schizophrenia. Journal of Abnormal Psychology 86, 103-126. 